\title{
Changes in functional, phylogenetic and taxonomic diversities of lowland fens under different vegetation and disturbance levels
}

\author{
Fabio Carvalho (D) Kerry A. Brown (1) - Martyn P. Waller (1) - Onja H. Razafindratsima (i) \\ Arnoud Boom
}

Received: 15 May 2019/Accepted: 31 March 2020/Published online: 9 April 2020

(C) The Author(s) 2020

\begin{abstract}
Multiple measures of plant diversity are vital to understand the response of plant communities to changing environmental conditions in peatlands. We assessed whether functional, phylogenetic and taxonomic diversities of woody and herbaceous fen peatlands in East Anglia, UK varied between plant communities under different management practices (mowing and grazing). We adjusted the weight of phylogenetic distances in a combined functionalphylogenetic distance matrix to assess functional and phylogenetic diversities separately and in combination. We tested the phylogenetic signal of four traits (leaf dry-matter content, leaf $\mathrm{N}$, leaf $\delta^{13} \mathrm{C}$ and leaf $\delta^{15} \mathrm{~N}$ ) and employed null models to determine patterns
\end{abstract}

Communicated by Anna R. Armitage.

Electronic supplementary material The online version of this article (https://doi.org/10.1007/s11258-020-01024-1) contains supplementary material, which is available to authorized users.

F. Carvalho $(\bowtie) \cdot$ K. A. Brown · M. P. Waller

Department of Geography, Geology and the Environment,

Kingston University London, Penrhyn Road,

Kingston upon Thames, Surrey KT1 2EE, UK

e-mail: fabiocgs@yahoo.com

Present Address:

F. Carvalho

Lancaster Environment Centre, Lancaster University,

Lancaster LA1 4YQ, UK of clustering and over-dispersion of traits and phylogenies. We used rarefaction to determine if observed taxonomic diversity was higher or lower than expected. Functional, phylogenetic and taxonomic diversities varied across and within vegetation types. Annual grazing was associated with reduced functional and phylogenetic diversities but was not significantly associated with taxonomic diversity. Annual mowing was associated with increased phylogenetic and taxonomic diversities. Multiple diversity metrics can provide complementary or contrasting information. While there are benefits to annual management of wetlands (benefitting rare species), these must be weighed against eroding functional and phylogenetic diversities that can potentially adversely affect responses to environmental change. Communities mown every seven to eight years supported characteristic fen vegetation and maintained high plant diversity across a range of measures. Our results sound a cautionary note of neglecting to monitor multiple plant diversity measures in managed habitats, since

\section{O. H. Razafindratsima}

Department of Natural Resource Management, South Dakota State University, Brookings, SD 57007, USA

\section{A. Boom}

School of Geography, Geology and the Environment, University of Leicester, Leicester LE1 7RH, UK 
attempts to maximize one may inadvertently lead to the erosion of others.

Keywords Community assembly · Mowing and grazing · Peatlands and wetlands · Plant traits . Rarefaction $\cdot$ Vegetation management

\section{Introduction}

It is becoming increasingly important to determine how multiple dimensions of plant diversity, including functional, phylogenetic and taxonomic diversities, respond to changing environmental conditions. This is particularly true for peatland environments, where ongoing land-use change and habitat losses are a threat to their biodiversity (Crump 2017). Plant diversity of fen peatlands can vary significantly and be influenced by a myriad of factors, including soil fertility (Øien et al. 2018), soil water level and chemistry (Navrátilová et al. 2017) and changes to hydrological conditions like drainage and rewetting (Mälson et al. 2008). Vegetation management practices like mowing (Kozub et al. 2019) and grazing (Merriam et al. 2018) can also affect fen plant diversity, since the abandonment of fens may result in changes to vegetation composition (Navrátilová et al. 2017) and the encroachment of shrubs over herb fens (Wheeler and Shaw 1995). Regular mowing and grazing and the maintenance of water and nutrient levels can have positive effects on the long-term survival of characteristic open fen vegetation (Stammel et al. 2003). However, management effects can be significantly influenced by the local environment and affect the response of fens to changing conditions (Middleton et al. 2006). It is thus crucial to assess multiple dimensions of plant diversity of fen peatlands to determine whether they show similar or contrasting results across different types of vegetation and conservation management practices.

Functional trait data provide crucial information to assess the ecology of a site and the response of plant diversity to changing conditions (Dainese et al. 2015). The diversity of traits captures the interspecific variability that arises from species-specific responses to environmental change, which has been identified as one of the key factors driving changes in the functional diversity of plant communities (Pakeman 2011). There is evidence that ecological communities with high functional diversity may be more resilient and better buffered against the vagaries of environmental change (Pillar et al. 2013), while changes in the range and variability of plant functional traits have been shown to be strong drivers of ecosystem processes (Díaz and Cabido 2001).

Equally, phylogenetic diversity may provide important information related to plant responses to changing conditions. Phylogenetic diversity reflects the evolutionary history of coexisting species and can elucidate their capacity to adapt to environmental change (Alberti et al. 2017), management practices (Kelly et al. 2015) and conservation efforts (Tucker and Cadotte 2013). Similar to functional diversity, plant communities with high phylogenetic diversity have the potential to buffer ecosystems against environmental change, possibly because interspecific complementarity effects enhance primary productivity and nutrient cycling (Hooper et al. 2005). However, those that show low phylogenetic diversity may reduce ecosystem stability (Cadotte et al. 2012) and productivity (Cadotte et al. 2008), perhaps due to ecological differentiation leading to reduced overlap in resource use between neighbouring species (e.g., niche partitioning; Heemsbergen et al. 2004).

Past studies have highlighted the importance of taxonomic diversity for ecosystem productivity (Hooper et al. 2005) given the positive relationship between plant species richness and primary production (Marquard et al. 2009). It is thought that increased species richness is responsible for higher plant nitrogen pools and more efficient nutrient use by the resident flora (Fargione et al. 2007), while complementarity effects may improve plant carbon uptake and translocation rates to produce more biomass per unit of nutrient in plant tissue (De Deyn et al. 2012). Whatever the mechanisms involved, it is clear that high plant diversity, expressed as either functional, phylogenetic or taxonomic diversity, is vital for the functioning of ecosystems and the delivery of important ecosystem services like biomass production and nutrient cycling.

This study aims to investigate the variability in plant functional, phylogenetic and taxonomic diversities of lowland fen plant communities dominated by different types of vegetation and under different conservation management practices (mowing and grazing). Fens are peat-forming environments occupying the seasonally and periodically flooded habitat 
zone between swamps and dry land that encompass several environmental gradients (e.g. water level, $\mathrm{pH}$, fertility; Wheeler and Proctor 2000). They have high taxonomic diversity (Wheeler and Giller 1982), strong habitat-trait interactions (Moor et al. 2017) and are frequently managed for long-term conservation purposes (Gauci 2008). Climate and topography are some of the major factors in the formation of fens (Wheeler and Shaw 1995), but management is known to be one of the main drivers in altering the composition of fen vegetation, since the existence of open herbaceous fens may be dependent upon grazing and/or mowing to maintain their structure and floristic composition (Wheeler and Shaw 1995).

There is a long history of studies documenting the interaction between vegetation management (particularly grazing), variation in primary productivity and plant community structure (sensu Cingolani et al. 2005; Milchunas et al. 1988; Westoby et al. 1989). However, we did not explicitly investigate whether variation in plant diversity was mediated through either a combination of moisture, nutrient or productivity gradient, and therefore do not offer a mechanistic explanation for our observations. Instead, we explore the probable causes behind the variability in plant diversity of our studied fens, with particular attention to their current management, and discuss the implications of our results to the long-term management and conservation of fen habitats.

\section{Materials and methods}

\section{Study sites}

We collected data from 157 sampling plots across two lowland fens in East Anglia, UK between the summers of 2013 and 2015 (Online Resource 1). The study sites contained woody and herbaceous vegetation that occurred on peat and were subject to different management methods (Table 1). Upton Broad $\left(52^{\circ}\right.$ $40^{\prime} \mathrm{N} 1^{\circ} 31^{\prime} \mathrm{E}$ ) is a 105-ha Nature Reserve surrounded by pasture and arable land, receiving surface water from a small local catchment dominated by drained pastureland (Bennion et al. 2001). The areas sampled comprised fen woodlands/carr and open herbaceous fens. The alder carr (with Alnus glutinosa and Fraxinus excelsior) and the mixed woods (with Betula pubescens, Quercus robur, and Salix cinerea) were unmanaged. The herbaceous fens included reedswamp with Phragmites australis and Carex riparia, as well as areas of Cladium and Juncus fens dominated by Calamagrostis canescens alongside Cladium mariscus and Juncus subnodulosus, respectively. All herbaceous communities were under mechanised mowing on a seven- to eight-year rotation during summer, with cuttings collected and removed. The reedswamp and Cladium fen were last mown before sampling in 2007, while the Juncus fen was last mown in 2011. Woodwalton Fen $\left(52^{\circ} 26^{\prime} \mathrm{N} 0^{\circ} 11^{\prime} \mathrm{W}\right)$ comprises an area of 205 ha of relict peatland surrounded by arable farmland, but isolated by raised flood banks. The areas sampled included alder carr, glades (herbaceous fens surrounded by woodlands) and areas of sedge fen, Phragmites fen and rush pasture. The carr was unmanaged and the result of steady scrub encroachment since before the 1940s due to a lack of vegetation clearance (Bowley 2015), being now dominated by $A$. glutinosa and Betula. The glades (with C. canescens and $P$. australis) were either unmown or annually mown in summer. The sedge fen was mown annually during summer and dominated by Carex viridula, $C$. panicea and Molinia. The Phragmites fen has remained unmown for $c$. 20 years before sampling and had $P$. australis, Carex acutiformis and $C$. canescens as the predominant species. The sedgeand Juncus-dominated rush pasture was cattle-grazed annually in autumn and last grazed before sampling in 2014 by 12 cows. C. acutiformis, C. panicea, Juncus articulatus and Glyceria fluitans dominated. Cuttings were collected and removed from sites under mechanised mowing. See Carvalho et al. (2019a; 2019b) and Waller et al. (2017) for further details of the sites.

\section{Leaf traits}

We selected leaf dry-matter content (LDMC), leaf N, leaf $\delta^{13} \mathrm{C}$ and leaf $\delta^{15} \mathrm{~N}$ because they were low to moderately correlated, providing independent trait variables (Online Resource 1) and because they are commonly related to a plant's photosynthetic rate, carbon assimilation strategy and nutrient turnover rates (Cernusak et al. 2009; Reich et al. 1999). LDMC and leaf $\mathrm{N}$ tend to be negatively related, and species with high leaf $\mathrm{N}$ tend to be characterised by high rates of resource acquisition and low resource conservation, normally associated with high photosynthetic and relative growth rates (Wright et al. 2004). These 
Table 1 Plant communities sampled at Upton Broad, Norfolk and Woodwalton Fen, Cambridgeshire

\begin{tabular}{|c|c|c|c|c|}
\hline Site & $\begin{array}{l}\text { Plant } \\
\text { community }\end{array}$ & $\begin{array}{l}\text { Date } \\
\text { sampled }\end{array}$ & Vegetation management & Main species \\
\hline \multirow[t]{5}{*}{ Upton Broad } & $\begin{array}{l}\text { Reedswamp } \\
\quad(\mathrm{RU})\end{array}$ & $\begin{array}{l}\text { September } \\
2013\end{array}$ & $\begin{array}{l}\text { Summer mown on a } 7 \text { - to } \\
\text { 8-year rotation (last cut } \\
\text { 2007) }\end{array}$ & Phragmites australis, Carex riparia, Calystegia sepium \\
\hline & $\begin{array}{l}\text { Cladium fen } \\
\quad(\mathrm{CU})\end{array}$ & $\begin{array}{l}\text { September } \\
2013\end{array}$ & $\begin{array}{l}\text { Summer mown on a } 7 \text { - to } \\
\text { 8-year rotation (last cut } \\
\text { 2007) }\end{array}$ & $\begin{array}{l}\text { Cladium mariscus, Calamagrostis canescens, Juncus } \\
\text { subnodulosus, Salix repens, Myrica gale }\end{array}$ \\
\hline & $\begin{array}{l}\text { Juncus fen } \\
\quad(\mathrm{JU})\end{array}$ & $\begin{array}{l}\text { September } \\
2013\end{array}$ & $\begin{array}{l}\text { Summer mown on a } 7 \text { - to } \\
\text { 8-year rotation (last cut } \\
\text { 2011) }\end{array}$ & $\begin{array}{l}\text { Juncus subnodulosus, Calamagrostis canescens, } \\
\text { Thelypteris palustris, Eupatorium cannabinum }\end{array}$ \\
\hline & $\begin{array}{l}\text { Alder carr } \\
(\mathrm{AU})\end{array}$ & May 2013 & None & Alnus glutinosa, Fraxinus excelsior, Carex acutiformis \\
\hline & $\begin{array}{l}\text { Mixed } \\
\text { woods } \\
\text { (MU) }\end{array}$ & May 2013 & None & $\begin{array}{l}\text { Betula pubescens, Quercus robur, Salix cinerea, } \\
\text { Dryopteris dilatata, Urtica dioica }\end{array}$ \\
\hline \multirow[t]{6}{*}{$\begin{array}{l}\text { Woodwalton } \\
\text { Fen }\end{array}$} & $\begin{array}{l}\text { Alder carr } \\
(\mathrm{AW})\end{array}$ & May 2014 & None & $\begin{array}{l}\text { Alnus glutinosa, Betula pubescens, Crataegus } \\
\text { monogyna, Poa trivialis, Urtica dioica, Glechoma } \\
\text { hederacea }\end{array}$ \\
\hline & $\begin{array}{l}\text { Glades } \\
\quad(\mathrm{GNW})\end{array}$ & $\begin{array}{c}\text { August } \\
2014\end{array}$ & $\begin{array}{l}\text { Left uncut for several years } \\
\text { (last cutting not recorded) }\end{array}$ & $\begin{array}{l}\text { Calamagrostis canescens, Phragmites australis, } \\
\text { Symphytum officinale }\end{array}$ \\
\hline & $\begin{array}{l}\text { Glades } \\
\text { (GMW) }\end{array}$ & $\begin{array}{c}\text { August } \\
2014\end{array}$ & Mown annually (summer) & $\begin{array}{l}\text { Calamagrostis canescens, Phragmites australis, Carex } \\
\text { acutiformis, Calystegia sepium }\end{array}$ \\
\hline & $\begin{array}{l}\text { Phragmites } \\
\text { fen (TW) }\end{array}$ & $\begin{array}{l}\text { September } \\
2014\end{array}$ & Uncut for $c .20$ years & $\begin{array}{l}\text { Phragmites australis, Carex acutiformis, } \\
\text { Calamagrostis canescens, Calystegia sepium, } \\
\text { Lysimachia vulgaris }\end{array}$ \\
\hline & $\begin{array}{l}\text { Sedge fen } \\
\quad(\mathrm{SW})\end{array}$ & July 2014 & Mown annually (summer) & $\begin{array}{l}\text { Carex viridula, Carex panicea, Molinia caerulea, } \\
\text { Hydrocotyle vulgaris }\end{array}$ \\
\hline & $\begin{array}{l}\text { Rush pasture } \\
(\mathrm{PW})\end{array}$ & June 2015 & $\begin{array}{l}\text { Cattle grazed annually in } \\
\text { autumn (last grazed 2014) }\end{array}$ & Carex spp., Juncus spp., Ranunculus flammula \\
\hline
\end{tabular}

Last cut and last grazed dates refer to the last time management intervention took place before sampling. Plant community codes are as shown in Online Resource 1: Fig. S1.1

differences in resource-use strategy may influence nutrient cycling through changes in decomposition rates of leaf litter (Cornwell et al. 2008). Leaf C and N isotopic data are useful for making inferences about species' water use efficiency and nutrient uptake from soils (Craine et al. 2009; Lai et al. 2004) that may have important consequences to ecosystem processes like plant-soil C fluxes (Staddon 2004).

\section{Cluster analysis}

We used cluster analysis as an objective way of grouping our field plots into vegetation communities based on similarities in species composition and abundance. All analyses presented here were performed on vegetation clusters rather than the communities observed in the field.

Species counts were converted into plot-level relative abundances with chord transformation (Euclidean distances computed on plot vectors normalized to length 1). This 'double' transformation allows for the use of standard linear methods with species data and preserves the asymmetrical distances between plots (Legendre and Gallagher 2001). We used the unweighted pair-group clustering method with arithmetic averages (UPGMA; Legendre and Legendre 1998) because it provided the highest Pearson correlation (0.91) and the lowest Gower distance (141.74) between the Euclidean and the cophenetic distance matrices. Plots with negative silhouette widths (a measure of the degree of 
membership of a plot to its cluster; Borcard et al. 2011) were excluded from the analysis. In addition, any plot from a field community that dropped out into another cluster was removed to preserve the integrity of field communities within clusters. After removing plots with low trait data coverage (Online Resource 1, page 3, lines 66 to 70), 112 plots distributed across seven clusters were left for analyses. We performed cluster analysis (and all analyses presented here) in R 3.6.1 (R Development Core Team 2019) using functions in vegan 2.5-6 (Oksanen et al. 2019) and cluster 2.1.0 (Maechler et al. 2019).

The alder-dominated woodlands in Upton and Woodwalton grouped into the alder carr cluster (22 plots). The mixed woods in Upton formed their own cluster (16 plots), as did the sedge fen (14 plots) and rush pasture (10 plots) in Woodwalton and the Cladium fen (7 plots) and reedswamp (10 plots) in Upton. The Juncus fen in Upton and the glades and Phragmites fen in Woodwalton grouped into the "herb fen' cluster (33 plots). We classified the clusters as wooded (alder carr and mixed woods), sedge-dominated (sedge fen, Cladium fen and rush pasture) and grass-dominated (herb fen and reedswamp) fens if the dominant life form (tree, sedge or grass) attained abundance cover greater than $25 \%$ at the community level.

\section{Phylogenetic signal of leaf traits}

Functional and phylogenetic diversities can explain ecological patterns in similar ways if the measured traits of closely related species have been conserved through time and show a high phylogenetic signal (Swenson et al. 2007). However, if traits have responded strongly to biotic and abiotic pressures, closely related species may display adaptive change and divergent traits with low phylogenetic signal (Gerhold et al. 2015; Silvertown et al. 2006). Therefore, testing for phylogenetic signal in traits may assist in the interpretation of phylogenetic patterns. Firstly, a phylogenetic tree that contained the 61 species 'hit' and with trait measurements (Online Resource 1) was built using Phylomatic v3 (Webb and Donoghue 2005). Phylomatic matches the taxa in the species list (family and genus) with the most resolved position possible in a userspecified megatree. We used the megatree 'zanne2014' (Zanne et al. 2014), a phylogenetic tree of angiosperms with calibrated branch lengths. We characterised the phylogenetic diversity (PD) of each sampling plot using Faith's PD measure (Faith 1992), which is the sum of all branch lengths in the portion of the phylogenetic tree connecting the focal set of species (Vellend et al. 2011). We then estimated the phylogenetic signal of each trait with functions in phytools (Revell 2012) to estimate Pagel's lambda (Pagel 1999). Pagel's lambda estimates the phylogenetic signal in a trait against a Brownian motion model of evolution, in which trait divergence and phylogenetic distance increase proportionally (estimated from 999 randomisations). Values of lambda range from 0 (no phylogenetic signal) to 1 (increasing phylogenetic signal).

Three of the four traits used to estimate functional distances were strongly phylogenetically conserved (Fig. 1). LDMC (Pagel's $\lambda=0.75, p<0.0001$ ), leaf $\mathrm{N}(\lambda=0.483, p=0.002)$ and leaf $\delta^{15} \mathrm{~N}(\lambda=0.88$, $p<0.001)$ revealed significant phylogenetic signals, but not leaf $\delta^{13} \mathrm{C}(\lambda=0.162, p=0.07$; Fig. 1$)$, indicating broad agreement between traits and phylogenies and suggesting that changes in phylogenetic diversity may be associated with changes in functional traits.

Functional-phylogenetic diversity (FPD)

We used a combined measure of functional-phylogenetic diversity (FPD) to assess how the functional and phylogenetic components of fen vegetation differed between plant communities generated by UPGMA clustering. FPD integrates trait and phylogenetic information following the combined functional-phylogenetic approach of Cadotte et al. (2013). It can potentially overcome the limitations of measures based exclusively on functional or phylogenetic distances (Mayfield and Levine 2010) by accounting for trait convergence and divergence when measuring phylogenetic distances (Cadotte et al. 2013; de Bello et al. 2017).

We used species abundances and four leaf traits (LDMC, leaf $\mathrm{N}$, leaf $\delta^{13} \mathrm{C}$ and $\delta^{15} \mathrm{~N}$ ) to estimate functional distances (FDist). We also used the phylogenetic distances (PDist) generated when estimating $\mathrm{PD}$ to calculate a single functional-phylogenetic distance matrix (FPDist), as described in Cadotte et al. (2013): 


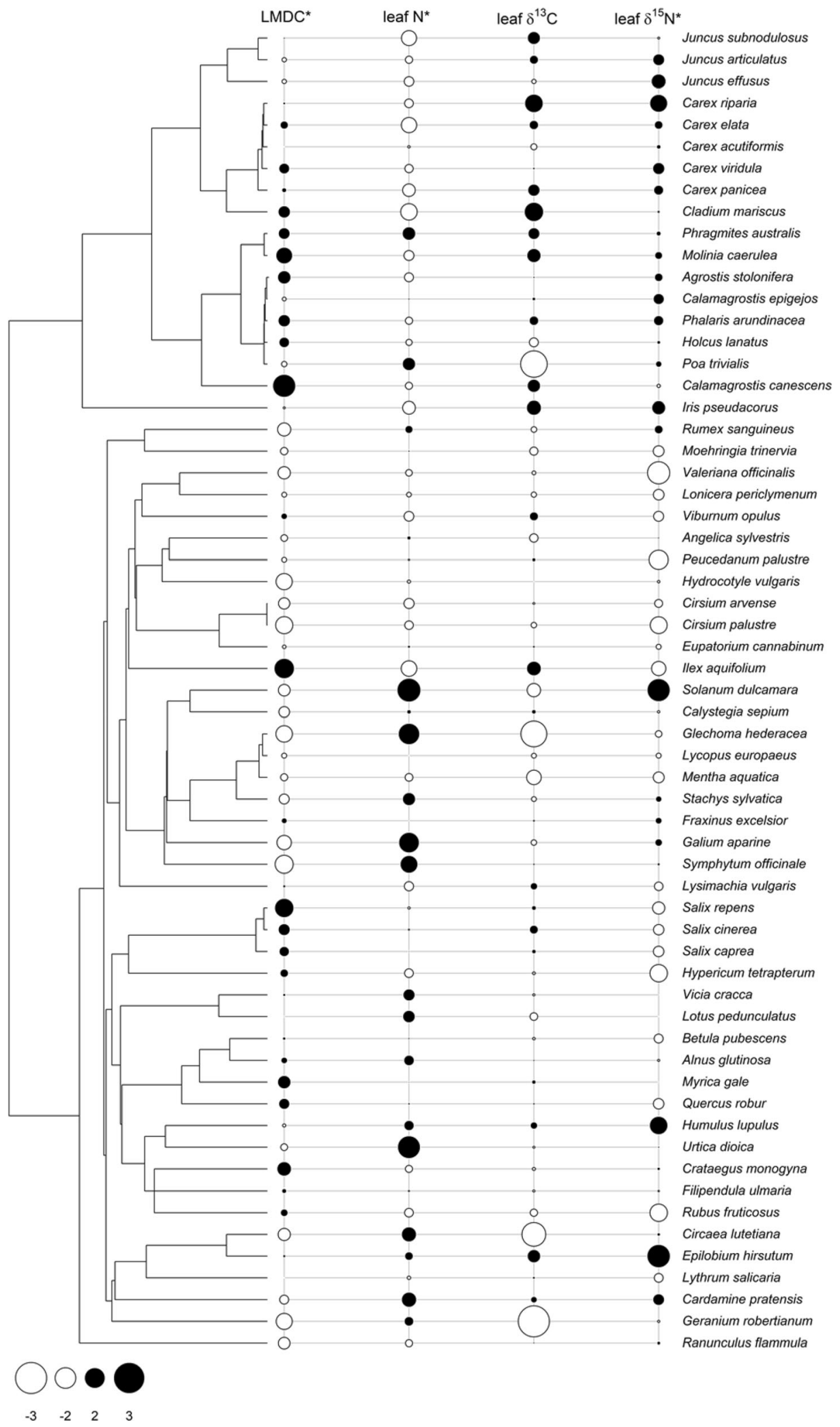


4Fig. 1 Phylogeny of the 61 vascular plant species from Upton and Woodwalton used in the analyses, with trait values (centred and standardised) shown on the tips. Asterisks next to trait labels indicate significant phylogenetic signal (Pagel's $\lambda>0$ ). White and black circles represent negative and positive scaled trait values, respectively (see legend)

$$
\text { FPDist }=\left(\text { aPDist } t^{\rho}+(1-a) F \text { Dist }^{\rho}\right)^{1 / \rho} .
$$

FPDist is a $p$-norm distance when $p \geq 1$ and PDist and FDist are distance metrics. Phylogenetic distances were square-rooted (Letten and Cornwell 2015) and both LDMC and leaf $\mathrm{N}$ were $\log _{10}$-transformed prior to FPDist computation.

The weighting parameter $a$ scales the relative contributions of FDist and PDist to the FPDist matrix in a way that when $a=0$ only FDist contributes to the combined distance matrix, and when $a=1$ only PDist is considered. Therefore, when $a=0.5$ both FDist and PDist contribute equally to FPDist. We varied $a$ from 0 to 1 using values of $0,0.5$ and 1 . We used the function funct.phylo.dist in pez (Pearse et al. 2015) to calculate FPDist.

The advantage of the FPDist matrix is that it can be used with any distance-based diversity measure (Cadotte et al. 2013). Therefore, in addition to calculating the mean pairwise functional-phylogenetic distance (MFPD) used by Cadotte et al. (2013; Online Resource 2), we used the FPDist matrix in a similar way to Si et al. (2017) and estimated FPD with the $d b F D$ function in $F D$ 1.0-12 (Laliberté and Legendre 2010; Laliberté et al. 2014). Principal Coordinate Analysis (pcoa function) was used to reduce the dimensions of the FPDist matrix to four axes with a total inertia of $>90 \%$. These four PCoA axes were supplied as a distance matrix of class dist to the $d b F D$ function to calculate FPD using all values of $a(0,0.5$ and 1). We used the functional dispersion (FDis) metric of Laliberté and Legendre (2010) to estimate FPD. FDis estimates the dispersion of species in trait space by computing the mean distance of coexisting species to the centroid of the whole community in multi-trait space (Laliberté and Legendre 2010). Since we used species abundance data, FDis was the weighted-mean distance of individual species to their weighted centroid (the centroid being the abundanceweighted community mean). Therefore, the subset of a community could be more diverse than the whole community if the species that were removed were relatively close to the centroid. Consequently, communities with relatively high FPD can be interpreted as having a higher number of species that are farther from the centroid (i.e. more dispersed in trait and phylogenetic space) than communities with relatively low FPD, where most species are closer to the centroid (i.e. closer to the community weighted-mean). Henceforth, FDis will be referred to as functional diversity for simplicity.

\section{Randomisation tests}

We compared plot-level observed FPD with those generated at random to determine patterns of clustering and/or over-dispersion in the trait and phylogenetic community data. Null communities were generated from random draws of species without replacement using all 61 species in the trait dataset. We randomised between communities (rather than within) because the most common species were found throughout the studied sites. The species richness of each simulated plot was kept the same as in the observed data. Standardised effect sizes (SES; Gotelli \& McCabe 2002) were determined to compare observed and expected values of FPD as

$\left(X_{\text {obs }}-X_{\text {null }}\right) / S D_{\text {null }}$,

where $X_{\mathrm{obs}}$ and $X_{\text {null }}$ are the observed FPD and the mean FPD of 999 simulated values, respectively, and $S D_{\text {null }}$ is the standard deviation of the simulated values. Positive values of SES indicate FPD dispersion (i.e. coexisting species are less related/similar than expected by chance) and negative values indicate FPD clustering (i.e. coexisting species are more closely related/similar than expected by chance). Next, we computed the mean SES of each community, as well as their $95 \%$ confidence intervals (using two-tailed Student's $t$ at $\alpha=0.025$ ), to determine if they were, on average, significantly different from random expectations (i.e. significantly different from zero). We estimated the probabilities of getting such results by determining the $p$ value of one-sample $t$ tests that assessed the deviation of SES values from random expectations (zero) for each community. 
Taxonomic diversity (TD)

We used the SES measure described above to compare the observed number of species with rarefied (expected) number of species. Rarefaction analysis estimates the means of repeated re-sampling of all pooled individuals and generates the expected number of species given a number of $n$ individuals drawn randomly from the large pool of $N$ individuals sampled (Gotelli and Colwell 2001). We used the function rarefy in vegan 2.5-6 (Oksanen et al. 2019) to estimate plot-level (individual-based) rarefied number of species. The rarefy function is based on Hurlbert's (1971) formulation. The size of random subsamples used for rarefying communities was 47 , the minimum number of individuals 'hit' in a given plot. We computed SES means and $95 \%$ confidence intervals of each community and used one-sample $t$ tests to determine their deviation from expectation.

\section{Data analyses}

We used linear mixed-effects models (LMMs) to determine differences in FPD and TD between communities. We used sites as random effects in the mixed models to assume a different baseline value (i.e. intercept) for the response variable of each plot (Zuur et al. 2009a). The SES values of TD and FPD (estimated for each value of $a$ ) were used as the response variables and plant communities (generated by UPGMA clustering) as the explanatory variable. We used the lme function in nlme 3.1-141 (Pinheiro et al. 2019) to fit LMMs to the data. We then compared these full models with null models (i.e. intercept-only models where only the means of the data were estimated) using log-likelihood ratio tests (Bolker et al. 2009) and the anova function to determine the magnitude of the differences in FPD and TD between communities $(p<0.05$ indicated significant differences). The $p$ value of the log-likelihood ratio statistic $(L)$ was corrected to follow the $L$ distribution instead of the Chi-square distribution (Zuur et al. 2009b). Lastly, we employed multiple pairwise comparisons using Fisher's least significant differences (LSD) on instances where there were significant differences in FPD and TD between communities (Sokal \& Rohlf 2012). LSD analyses were performed using a modified version of the LSD.test function in agricolae 1.3-1 (de Mendiburu 2019).

\section{Results}

Correlations between functional and phylogenetic distances

The weights of functional and phylogenetic distances were evenly distributed when using $a=0.5$, since the correlations between $a=0.5$ and $a=0 \quad(r=0.79$, $d f=110, \quad p<0.001 ; \quad$ Pearson correlation) and between $a=0.5$ and $a=1 \quad(r=0.80, d f=110$, $p<0.001$; Pearson correlation) were virtually indistinguishable. Functional $(a=0)$ and phylogenetic $(a=1)$ diversities were moderately correlated across communities $(r=0.55, d f=110, p<0.001$; Pearson correlation), but showed low to high correlations within communities (Online Resource 2).

Functional-phylogenetic (FPD) and taxonomic (TD) diversities of fen plant communities

There were significant differences in functional-phylogenetic diversity (FPD) between and within wood-, sedge- and grass-dominated communities, irrespective of the value of $a$ used to estimate FPD ( $p<0.05$; LMM analysis; see the log-likelihood ratio test results in panels a to c of Fig. 2). Taxonomic diversity (TD) also varied significantly across communities ( $p<0.05$; LMM analysis; Fig. $2 \mathrm{~d}$ ). The mixed woods and rush pasture showed the lowest functional (Fig. 2a) and phylogenetic (Fig. 2c) diversities ( $p<0.05$; LSD analysis). The reedswamp, herb fen and Cladium fen presented the highest functional diversity (Fig. 2a), while the reedswamp also revealed the highest phylogenetic diversity of all communities (Fig. 2c; $p<0.05$; LSD analysis). There were similar results when weighting functional and phylogenetic diversities equally (Fig. 2b), with the reedswamp the most diverse community and the mixed woods and rush pasture the least diverse ( $p<0.05$; LSD analysis). However, taxonomic diversity was lowest in the reedswamp and highest in the other herbaceous fens, irrespective of being sedge- or grass-dominated (Fig. 2d; $p<0.05$; LSD analysis).

Deviation from random expectations

One-sample $t$ tests (Online Resource 2) revealed that clustering of traits and phylogenies were more pronounced in the mixed woods and rush pasture 
a

$$
\text { FPD }(a=0)
$$

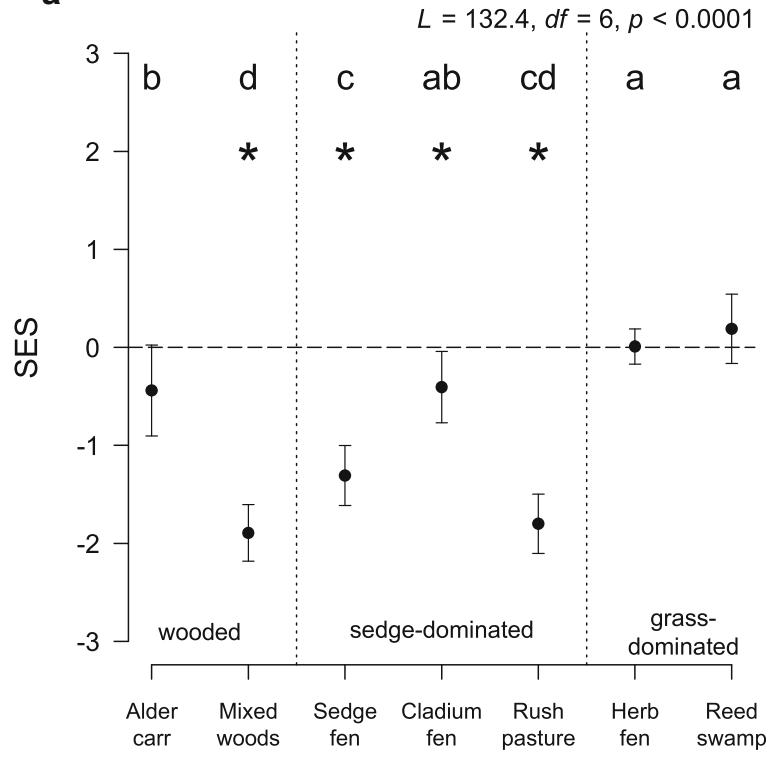

$\operatorname{FPD}(a=1)$

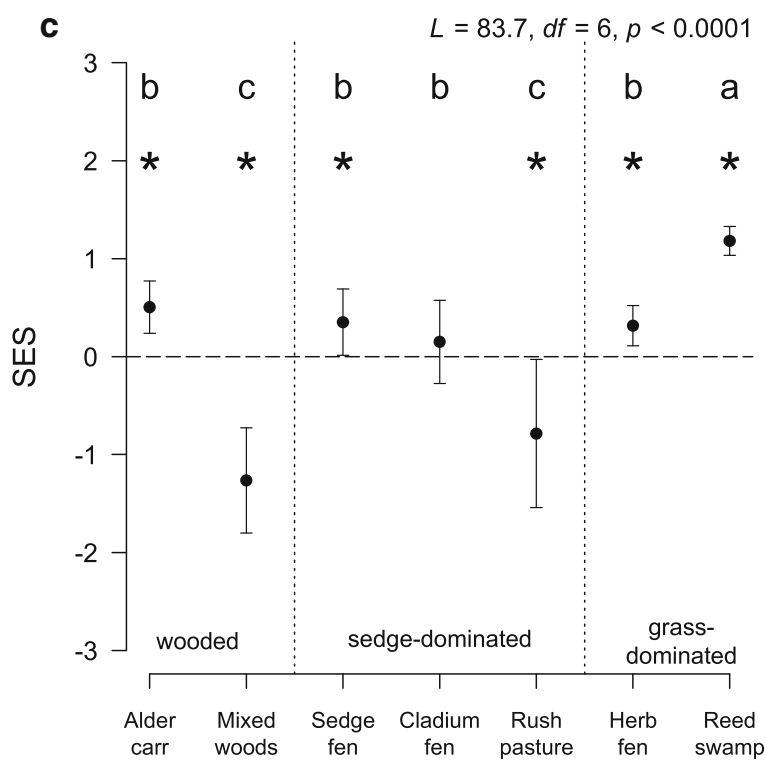

Fig. 2 Mean standardised effect sizes (SES) of functionalphylogenetic diversity (FPD; panels a to c) and taxonomic diversity (TD; panel d) of plant communities generated by UPGMA clustering, arranged by wood-, sedge- or grassdominated communities. The value of $a$ shown at the top of each FPD panel (a to c) indicates the proportional contribution of phylogenetic distances when calculating the functionalphylogenetic distance matrices (i.e. only functional distances are considered when $a=0$, only phylogenetic distances when $a=1$ and both functional and phylogenetic distances when $a=0.5$ ). Error bars not overlapping with the zero line (denoted
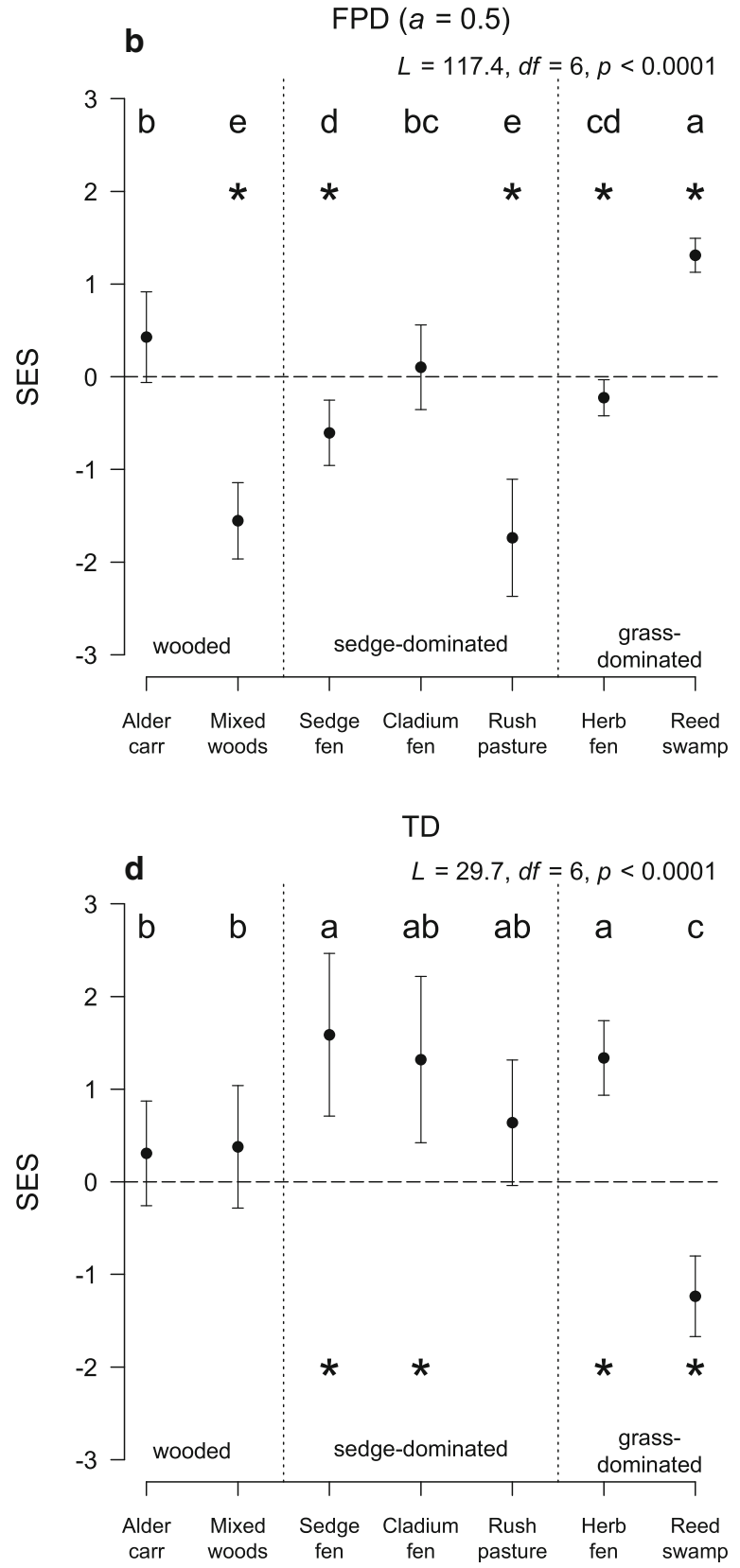

by an asterisk) indicate significant departure from random expectation $(p<0.05)$ following one-sample $t$ tests $(95 \%$ confidence intervals). Positive values of SES indicate overdispersion (i.e. coexisting species are less similar/related than expected by chance) and negative values indicate clustering (i.e. coexisting species are more similar/related than expected by chance). Results of the log-likelihood ratio tests are shown at the top right-hand side of each panel ( $L=$ ratio statistic; $d f=$ degrees of freedom). Different letters above each data point indicate significant differences $(p<0.05)$ between means following Fisher's least significant differences (LSD) 
(Fig. 2a and c). None of the fen communities showed trait over-dispersion (Figs. 2a and 3), but the alder carr, herb fen, sedge fen, and reedswamp were phylogenetically over-dispersed (Figs. 2c and 3). When weighting functional and phylogenetic diversities equally, the reedswamp was the only community to show higher than expected diversity (Fig. 2b). The sedge fen showed contrasting responses depending on whether functional or phylogenetic diversity was emphasized, revealing trait clustering but phylogenetic over-dispersion (Fig. 2a, c and 3). The herb fen, Cladium fen and sedge fen were taxonomically overdispersed, but the reedswamp presented lower than expected TD (Fig. 2d). None of the wooded communities deviated from random expectation in taxonomic diversity (Fig. 2d).

\section{Discussion}

Differences in FPD and TD between fen plant communities

Fen plant communities dominated by different types of vegetation (woody, sedge- and grass-dominated) showed significantly different functional, phylogenetic and taxonomic diversities. Our results confirmed that filtering due to environmental constraints and competitive interactions, both mediated through

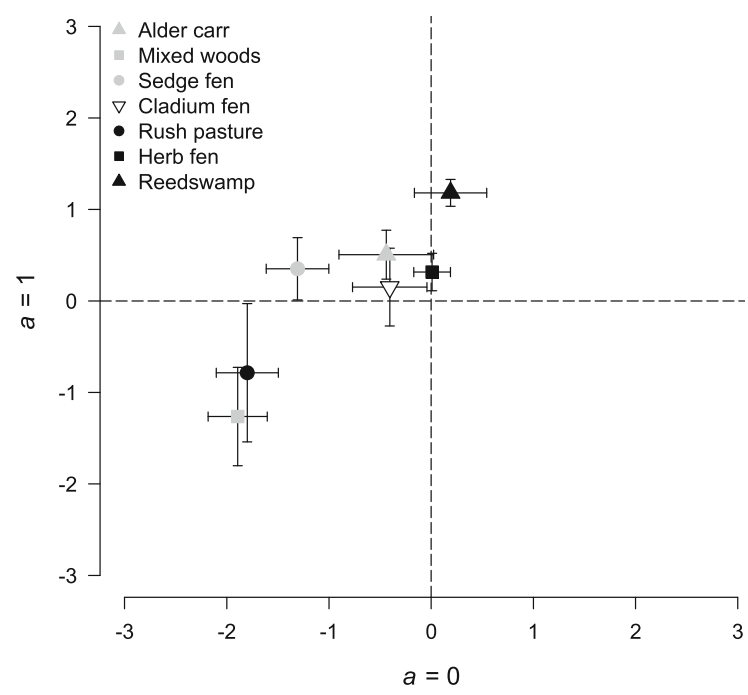

Fig. 3 Mean SES values of functional $(a=0)$ and phylogenetic $(a=1)$ diversities of plant communities generated by UPGMA clustering. Error bars denote $95 \%$ confidence intervals management practices, may not be mutually exclusive, since our diversity metrics exhibited clustered, over-dispersed and random patterns of co-occurring species within and between different types of vegetation. For instance, while functional diversity was relatively low in the sedge fen community, one of the annually mown sites, phylogenetic and taxonomic diversities were relatively high, suggesting that the plant diversity metrics used here were decoupled from one another. Therefore, one metric (functional diversity) suggested community homogenization while others (phylogenetic and taxonomic diversities) showed over-dispersion under the same type of dominant vegetation. These results highlight the importance of measuring multiple diversity metrics because they may provide complementary information or contrasting outcomes (Carmona et al. 2012).

Among the wooded communities, the alder carr showed higher FPD than the mixed woods, possibly due to its diverse field layer with slender grasses (e.g. Poa trivialis), shade-tolerant species (e.g. Geranium robertianum) and nutrient-demanding forbs (e.g. Urtica dioica and Galium aparine). The N-fixing ability of Alnus glutinosa (Eickenscheidt et al. 2014), the main tree species in the alder carr, may be driving additional $\mathrm{N}$ input to soil and promoting niche complementarity among neighbouring species with diverse resource-use strategies (Kahmen et al. 2006). On the other hand, important woody species in the mixed woods (e.g. Lonicera periclymenum and Salix cinerea) showed relatively similar leaf trait values to the main tree species (Betula pubescens and Quercus robur), suggesting clustered occupancy in leaf trait space and short phylogenetic distances between the dominant species, consistent with patterns of habitat filtering (Cornwell et al. 2006). It appears these dominant taxa have relatively similar strategies to compete for light and nutrients and exert similar effects on soil decomposition processes given the type of traits we analysed (measures of leaf dry mass and nutrient content). Therefore, the development of fen carr over herbaceous fen due to a lack of vegetation management (Bowley 2015) and a water table that is low enough in winter to allow the establishment of woody species (Duffey 1971; Poore 1956) seems to have promoted some degree of niche differentiation in the alder carr and the co-existence of dominant species with similar traits adapted to local conditions in the mixed woods. These contrasting pathways are 
probably being driven by differences in environmental variables between the two communities influenced by localised nutrient enrichment, soil chemistry, water table height and peat depth (Øien et al. 2018; Pillar et al. 2009).

The general increase in FPD from the wooded to the mown herbaceous fens may be the result of variation in resource partitioning between perennials and pioneer-type species (Golodets et al. 2009; Westoby 1998) with adaptations for rapid growth between disturbances and changes in nutrient uptake to maximise opportunities for establishment. For instance, the annual Galium aparine and the biennial Cirsium palustre were relatively abundant in the mown sites. They branched separately to the perennial monocotyledons in the phylogenetic tree (Fig. 1) and have lower leaf dry mass than grass-like plants to facilitate rapid growth. The relatively high abundance of certain forb species like Urtica dioica and Epilobium hirsutum may, in fact, be indicative of localised nutrient enrichment and may have contributed to the high FPD values of the reedswamp in Upton. Wetter, nutrientenriched conditions may also help explain the local dominance of Phragmites reedswamp over Cladium fen in some areas in Upton.

Despite the importance of habitat filtering and interspecific competition in influencing plant diversity (Díaz et al. 1998), disturbance caused by management intervention (e.g. mowing, grazing) can interact with environmental filters and alter plant-environment relationships in fens (Kozub et al. 2019). The apparent erosion of functional diversity in the annually mown and grazed sites (sedge fen and rush pasture, respectively) may be due to the dominance of species with a specific set of traits well adapted to mechanised mowing and grazing pressure that can affect fens through surface homogenisation and peat compression (Kotowski et al. 2013). The dominance of monocotyledons (e.g. Carex acutiformis, Carex viridula, Carex panicea, Molinia caerulea, Juncus articulatus) over dicotyledonous forbs in the annually managed sites may be due to their ability to regrow following disturbance due to growing points located close to the ground (at the base of leaves) that are less likely to be removed (Pollock et al. 2007). Molinia caerulea, the most abundant grass in the annually mown sedge fen in Woodwalton, can form dense tussocks and outcompete its neighbours due to its plasticity in the spatial allocation of leaves, vigorous belowground growth and shortened reproductive cycles (Aerts et al. 1991; Friedrich et al. 2011; Taylor et al. 2001). However, the sedge fen was floristically rich in terms of phylogenetic and taxonomic diversities, probably due to the conspicuous presence of forbs like Hydrocotyle vulgaris, Lysimachia vulgaris, Lythrum salicaria, Ranunculus flammula and Galium uliginosum. It is possible defoliation of $M$. caerulea is frequent enough to reduce tiller formation and the vigour of its belowground organs (Taylor et al. 2001), allowing light penetration and the establishment of a diverse floristic layer with similar leaf traits adapted to regular mowing.

Juncus spp., with hard and thick leaves, were the most abundant in the grazed sites (e.g. J. articulatus, $J$. subnodulosus, J. effusus). They have high resistance to grazing and disturbance and tend to form dense tussock structures that deter the establishment of other flowering plants (Vinther and Hald 2000). They branched close together in the phylogenetic tree, which contributed to reduce the phylogenetic diversity of the rush pasture. Cattle grazing has been found to favour certain plant traits and to cause shifts in community trait composition (Stammel et al. 2003). For instance, it can benefit species with high light requirements like J. articulatus (Hill et al. 2004). Past studies of management intervention in fen systems have indeed demonstrated that fast-growing generalist species tend to persist through regular long-term mowing and grazing to produce vegetation resembling a rush community where tall monocotyledons with similar growth forms and evolutionary history prevail (Kołos and Banaszuk 2013).

TD was generally higher in most of the mown herbaceous fens compared to the wooded fens. Biomass removal through mowing can increase light availability at the ground level through litter reduction and favour low-growing herbaceous vegetation, as well as some rare fen orchids (Middleton et al. 2006; Moen and Øien 2002). However, the reedswamp presented the lowest TD despite consistently showing some of the highest FPD, suggesting only a few shadetolerant species with a diverse set of traits have established under competition from the vigorous growth of $P$. australis (e.g. Carex riparia, Calystegia sepium, Solanum dulcamara, Eupatorium cannabinum). Contrarily, the Cladium fen community showed some of the highest TD, despite revealing clustered or random patterns of FPD. Other studies found a strong 
management-species richness interaction in Cladiumdominated communities due to reduction in summer biomass and the rehabilitation of early successional species under increased light availability (Menichino et al. 2016; Wheeler and Giller 1982). However, the long-term mechanised mowing and summer biomass removal of the Cladium fen community in Upton may have contributed to peat compaction and reduced availability of $\mathrm{N}$ and $\mathrm{P}$, favouring the dominance of several monocotyledons with similar functional traits capable of establishing in nutrient-poor conditions with reduced water flow and nutrient input compared to swampy conditions (e.g. Calamagrostis canescens; Wheeler 1980).

Despite the strong phylogenetic signal of three of the four traits used, the combined FPD measure revealed nuances in the data that were not apparent when using functional and phylogenetic diversities separately. It is possible that unmeasured traits may have different amounts of conservatism and convergence/divergence along phylogenies (Cadotte et al. 2013). Opposing effects of unmeasured traits may thus justify the use of metrics that combine both traits and phylogenies since they may provide complementary information and are able to partition functional and phylogenetic diversities (de Bello et al. 2017; Mayfield and Levine 2010). For instance, these metrics may prove to be valuable tools when assessing processes of plant community assembly when setting up restoration programs. These findings lend support to the argument of Cadotte et al. (2013) that joint functional and phylogenetic interspecific distances better represent true functional distances between plant species when using only a selection of ecologically relevant traits, possibly because this combined measure deals with different rates of trait evolution implicitly and accounts for unmeasured, phylogenetically correlated traits.

Implications for fen vegetation management

Historically, the main objectives of vegetation management applied to open fens have been to prevent the development of fen carr vegetation and to maintain characteristic species of herbaceous fens (Stammel et al. 2003). However, our results and other findings (Salgado-Luarte et al. 2019) should help to inform discussions about fen management in the UK. Even if challenging from a practical standpoint, monitoring functional and phylogenetic diversities is a worthwhile aid to enhance management strategies. Failure to consider these factors risks erosion of both (or either) components of diversity, which may affect communities' resilience and capacity to adapt to shortand long-term environmental change (Donoghue 2008). There is evidence that communities with coexisting species that are more closely related may lead to reduced ecosystem stability and productivity, while distantly related species might contribute more to biomass production and the diversity of responses to disturbance due to increased niche breadth and higher diversity of resource-use strategies (Cadotte et al. 2008, 2012). Research assessing the vulnerability of communities to environmental change due to changes in functional-phylogenetic diversity might be relatively new. However, there may be sufficient evidence to support a management strategy that seeks to increase fen resilience by also monitoring functional and phylogenetic diversities.

Our findings showed that annual cattle grazing and mowing were associated with reduced functional and phylogenetic diversities, while taxonomic diversity showed mostly opposite results. Sites mown every seven to eight years seem to have supported characteristic herbaceous fen communities with the added benefit of promoting enhanced functional diversity (as was the case with the herb fen community). Our results are in accordance with other studies that found mowing every four to five years to be better at promoting the long-term sustainability of sedge meadows (Kołos and Banaszuk 2018). The intensity of grazing or mowing has been found to influence the characteristic resident flora and either the dominance of tall monocotyledons or the prevalence of small forbs and slender grasses (McBride et al. 2011). Intensive grazing can lead to peat compaction and desiccation through hydrological alteration due to livestock trampling (Middleton et al. 2006), but extensive cattle grazing may be beneficial to fen ecosystems in reducing litter accumulation and preventing the dominance of tall-statured over shortstatured species (Bergamini et al. 2001). It is also considered a good alternative conservation strategy to mowing as it promotes similar amounts of typical fen species and Red Data Book species (Stammel et al. 2003). However, the duration and intensity of grazing and mowing must be carefully considered to avoid excessive biomass accumulation that can result in the 
loss of plant diversity (Kołos and Banaszuk 2013). Fluctuations in the frequency of grazing and mowing may directly affect nutrient availability to plants (Schrautzer et al. 2013) and competitive interactions between species (Fossati and Pautou 1989) through changes in vegetative biomass. For instance, changes in nutrient status due to lower frequency management can trigger succession towards non-fen vegetation that can outcompete fen specialists under increased nutrient availability (Navrátilová et al. 2017). Reducing the frequency of mowing and/or grazing may also be detrimental to TD (Isselstein et al. 2002) and tiller forming grasses that are often encouraged by annual grazing (Bullock et al. 1994). In addition, biomass accumulation under reduced herbivory might encourage competitive perennials over annual rarer species (Middleton et al. 2006) and lead to a decrease in peatforming moss species (Merriam et al. 2018) due to reduced light availability for prostrate plants (Mälson et al. 2008). These alternative management outcomes must therefore be weighed against the potential of eroding functional and phylogenetic diversities, since these components of diversity can potentially impact short- and long-term responses to environmental change.

In conclusion, annually mown herbaceous fens were associated with lower and clustered functional diversity, while annual cattle grazing also seems to have contributed to reduced phylogenetic diversity. Therefore, despite the potential for vegetation management to stabilise fen communities (Hájek et al. 2019) and enhance TD (Wheeler and Shaw 1995), annual management seems to have eroded the phylogenetic and functional components of lowland fens in this region. Recent studies in other ecosystems (e.g. tropical forests; Razafindratsima et al. 2018) have found similar results. It is important to note that other plant traits not used in this study could have yielded different results, particularly traits measured from different plant organs such as stems and roots. Disturbance, if applied at suboptimal intensity levels, can modulate decreased functional and phylogenetic diversities, which may not be reflected in measures of species richness. Our results sound a cautionary note to conservation management practitioners, since functional and phylogenetic diversities may be progressively eroded in the face of frequent disturbance, and unless directly measured, such decreases may go unnoticed.
Acknowledgements We are grateful to Marc W. Cadotte for thoughtful comments that helped improve the quality of this manuscript, and to William D. Pearse for help using the pez package in $\mathrm{R}$ and for useful comments on phylogenetic diversity analysis. We thank Alan Bowley and Craig Bellwood at Natural England and Debs Kershaw at the Norfolk Wildlife Trust for access to Woodwalton Fen and Upton Broad, respectively. FC was funded through a $\mathrm{PhD}$ studentship from the Faculty of Science, Engineering and Computing at Kingston University London. Field work and laboratory analyses were supported by the Department of Geography, Geology and the Environment at Kingston University London.

Author contributions $\mathrm{KAB}, \mathrm{FC}$ and MPW conceived the ideas. FC, MPW and KAB conducted fieldwork and collected the data. OHR performed phylogenetic diversity analysis. FC and $\mathrm{AB}$ conducted nitrogen and isotopic analyses of leaf samples. FC performed FPD and all other statistical analyses and wrote drafts of the manuscript. All authors contributed substantially through additions and revisions and gave final approval for publication.

Data availability Should this manuscript be accepted, the data supporting the results will be archived in a public repository (Dryad or Figshare) and the data DOI will be included at the end of the article.

\section{Compliance with ethical standards}

Conflict of interest The authors declare that they have no conflict of interest.

Open Access This article is licensed under a Creative Commons Attribution 4.0 International License, which permits use, sharing, adaptation, distribution and reproduction in any medium or format, as long as you give appropriate credit to the original author(s) and the source, provide a link to the Creative Commons licence, and indicate if changes were made. The images or other third party material in this article are included in the article's Creative Commons licence, unless indicated otherwise in a credit line to the material. If material is not included in the article's Creative Commons licence and your intended use is not permitted by statutory regulation or exceeds the permitted use, you will need to obtain permission directly from the copyright holder. To view a copy of this licence, visit http://creativecommons.org/licenses/by/4.0/.

\section{References}

Aerts R, Boot RGA, van der Aart PJM (1991) The relation between above- and belowground biomass allocation patterns and competitive ability. Oecologia 87:551-559

Alberti M, Correa C, Marzluff JM, Hendry AP, Palkovacs EP, Gotanda KM, Hunt VM, Apgar TM, Zhou Y (2017) Global urban signatures of phenotypic change in animal and plant populations. Proc Natl Acad Sci. https://doi.org/10.1073/ pnas. 1606034114 
Bennion H, Appleby PG, Phillips GL (2001) Reconstructing nutrient histories in the Norfolk Broads, UK: implications for the role of diatom-total phosphorus transfer functions in shallow lake management. J Paleolimnol 26:181-204

Bergamini A, Peintinger M, Schmid B, Urmi E (2001) Effects of management and altitude on bryophyte species diversity and composition in montane calcareous fens. Flora 196:180-193

Bolker BM, Brooks ME, Clark CJ, Geange SW, Poulsen JR, Stevens MHH, White J-SS (2009) Generalized linear mixed models: a practical guide for ecology and evolution. Trends Ecol Evol 24:127-135

Borcard D, Gillet F, Legendre P (2011) Numerical ecology with R. Springer, New York

Bowley A. 2015. Woodwalton Fen NNR management plan 2015-2020. Natural England, Available at https://www. wcidb.org.uk/download/i/mark_dl/u/4012836030/ 4622641480/WWFen MPlan 2015.pdf.

Bullock JM, Hill BC, Silvertown J (1994) Tiller dynamics of two grasses-responses to grazing, density and weather. J Ecol 82:331-340

Cadotte M, Albert CH, Walker SC (2013) The ecology of differences: assessing community assembly with trait and evolutionary distances. Ecol Lett 16:1234-1244

Cadotte MW, Cardinale BJ, Oakley TH (2008) Evolutionary history and the effect of biodiversity on plant productivity. Proc Natl Acad Sci 105:17012-17017

Cadotte MW, Dinnage R, Tilman D (2012) Phylogenetic diversity promotes ecosystem stability. Ecology 93:S223S233

Carmona CP, Azcárate FM, de Bello F, Ollero HS, Lepš J, Peco B (2012) Taxonomical and functional diversity turnover in Mediterranean grasslands: interactions between grazing, habitat type and rainfall. J Appl Ecol 49:1084-1093

Carvalho F, Brown KA, Waller MP, Boom A (2019a) Leaf traits interact with management and water table to modulate ecosystem properties in fen peatlands. Plant Soil 441:331-347

Carvalho F, Brown KA, Waller MP, Bunting MJ, Boom A, Leng MJ (2019b) A method for reconstructing temporal changes in vegetation functional trait composition using Holocene pollen assemblages. PLoS ONE 14(5):e0216698

Cernusak LA, Tcherkez G, Keitel C, Cornwell WK, Santiago LS, Knohl A, Barbour MM, Williams DG, Reich PB, Ellsworth DS, Dawson TE, Griffiths HG, Farquhar GD, Wright IJ (2009) Why are non-photosynthetic tissues generally ${ }^{13} \mathrm{C}$ enriched compared with leaves in $\mathrm{C} 3$ plants? Review and synthesis of current hypotheses. Funct Plant Biol 36:199-213

Cingolani AM, Noy-Meir I, Díaz S (2005) Grazing effects on rangeland diversity: a synthesis of contemporary models. Ecol Appl 15:757-773

Cornwell WK, Cornelissen JHC, Amatangelo K, Dorrepaal E, Eviner VT, Godoy O, Hobbie SE, Hoorens B, Kurokawa H, Pérez-Harguindeguy N, Quested HM, Santiago LS, Wardle DA, Wright IJ, Aerts R, Allison SD, Van Bodegom P, Brovkin V, Chatain A, Callaghan TV, Díaz S, Garnier E, Gurvich DE, Kazakou E, Klein JA, Read J, Reich PB, Soudzilovskaia NA, Vaieretti MV, Westoby M (2008) Plant species traits are the predominant control on litter decomposition rates within biomes worldwide. Ecol Lett 11:1065-1071

Cornwell WK, Schwilk DW, Ackerly DD (2006) A trait-based test for habitat filtering: convex hull volume. Ecology 87:1465-1471

Craine JM, Elmore AJ, Aidar MPM, Bustamante M, Dawson TE, Hobbie EA, Kahmen A, Mack MC, McLauchlan KK, Michelsen A, Nardoto GB, Pardo LH, Peñuelas J, Reich PB, Schuur EAG, Stock WD, Templer PH, Virginia RA, Welker JM, Wright IJ (2009) Global patterns of foliar nitrogen isotopes and their relationships with climate, mycorrhizal fungi, foliar nutrient concentrations, and nitrogen availability. New Phytol 183:980-992

Crump J. 2017. Smoke on water - countering global threats from peatland loss \& degradation. United Nations Environment Programme and GRID-Arendal, available at https://www. grida.no/publications/355.

Dainese M, Leps J, de Bello F (2015) Different effects of elevation, habitat fragmentation and grazing management on the functional, phylogenetic and taxonomic structure of mountain grasslands. Perspect Plant Ecol Evol Syst 17:44-53

de Bello F, Šmilauer P, Diniz-Filho JAF, Carmona CP, Lososová Z, Herben T, Götzenberger L (2017) Decoupling phylogenetic and functional diversity to reveal hidden signals in community assembly. Methods Ecol Evol 8:1200-1211

De Deyn GB, Quirk H, Oakley S, Ostle NJ, Bardgett RD (2012) Increased plant carbon translocation linked to overyielding in grassland species mixtures. PLoS ONE 7:10.1371/ journal.pone.0045926

de Mendiburu F (2019) Agricolae: statistical procedures for agricultural research. R package version 1.3-1, https:// cran.r-project.org/package=agricolae.

Díaz S, Cabido M (2001) Vive la difference: plant functional diversity matters to ecosystem processes. Trends Ecol Evol 16:646-655

Díaz S, Cabido M, Casanoves F (1998) Plant functional traits and environmental filters at a regional scale. J Veg Sci 9:113-122

Donoghue MJ (2008) A phylogenetic perspective on the distribution of plant diversity. Proc Natl Acad Sci 105:11549-11555

Duffey E (1971) The management of Woodwalton Fen: a multidisciplinary approach. In: Duffey E, Watt AS (eds) The scientific management of animal and plant communities for conservation. Blackwell Scientific Publications, Oxford

Eickenscheidt T, Heinichen J, Augustin J, Freibauer A, Drösler M (2014) Nitrogen mineralization and gaseous nitrogen losses from waterlogged and drained organic soils in a black alder (Alnus glutinosa (L.) Gaertn.) forest. Biogeosciences 11:2961-2976

Faith DP (1992) Conservation evaluation and phylogenetic diversity. Biol Cons 61:1-10

Fargione J, Tilman D, Dybzinski R, Lambers JHR, Clark C, Harpole WS, Knops JMH, Reich PB, Loreau M (2007) From selection to complementarity: shifts in the causes of biodiversity-productivity relationships in a long-term biodiversity experiment. Proc Biolog Sci 274:871-876 
Fossati J, Pautou G (1989) Vegetation dynamics in the fens of Chautagne (Savoie, France) after the cessation of mowing. Vegetatio 85:71-81

Friedrich U, von Oheimb G, Dziedek C, Kriebitzsch W-U, Selbmann K, Härdtle W (2011) Mechanisms of purple moor-grass (Molinia caerulea) encroachment in dry heathland ecosystems with chronic nitrogen inputs. Environ Pollut 159:3553-3559

Gauci V (2008) Carbon balance and offset potential of the Great Fen Project. The Open University and GLCC.

Gerhold P, Cahill JF, Winter M, Bartish IV, Prinzing A (2015) Phylogenetic patterns are not proxies of community assembly mechanisms (they are far better). Funct Ecol 29:600-614

Golodets C, Sternberg M, Kigel J (2009) A community-level test of the leaf-height-seed ecology strategy scheme in relation to grazing conditions. J Veg Sci 20:392-402

Gotelli NJ, Colwell RK (2001) Quantifying biodiversity: procedures and pitfalls in the measurement and comparison of species richness. Ecol Lett 4:379-391

Gotelli NJ, McCabe DJ (2002) Species co-occurrence: a metaanalysis of J M Diamond's assembly rules model. Ecology 83:2091-2096

Hájek M, Horsáková V, Hájková P, Coufal R, Dítě D, Němec T, Horsák M (2019) Habitat extremity and conservation management stabilise endangered calcareous fens in a changing world. Sci Total Environ. https://doi.org/10. 1016/j.scitotenv.2019.134693

Heemsbergen DA, Berg MP, Loreau M, van Hal JR, Faber JH, Verhoef HA (2004) Biodiversity effects on soil processes explained by interspecific functional dissimilarity. Science 306:1019-1020

Hill MO, Preston CD, Roy DB (2004) Plantatt - attributes of British and Irish plants: status, size, life history, geography and habitats. Centre for Ecology \& Hidrology, Huntingdon, Cambridgeshire, UK

Hooper DU, Chapin FS, Ewel JJ, Hector A, Inchausti P, Lavorel S, Lawton JH, Lodge DM, Loreau M, Naeem S, Schmid B, Setälä H, Symstad AJ, Vandermeer J, Wardle DA (2005) Effects of biodiversity on ecosystem functioning: a consensus of current knowledge. Ecol Monogr 75:3-35

Hurlbert SH (1971) The nonconcept of species diversity: a critique and alternative parameters. Ecology 52:577-586

Isselstein J, Tallowin JRB, Smith REN (2002) Factors affecting seed germination and seedling establishment of fen-meadow species. Restor Ecol 10:173-184

Kahmen A, Renker C, Unsicker SB, Buchmann N (2006) Niche complementarity for nitrogen: an explanation for the biodiversity and ecosystem functioning relationship? Ecology $87: 1244-1255$

Kelly SL, Song H, Jenkins DG (2015) Land management practices interactively affect wetland beetle ecological and phylogenetic community structure. Ecol Appl 25:891-900

Kołos A, Banaszuk P (2013) Mowing as a tool for wet meadows restoration: effect of long-term management on species richness and composition of sedge-dominated wetland. Ecol Eng 55:23-28

Kołos A, Banaszuk P (2018) Mowing may bring about vegetation change, but its effect is strongly modified by hydrological factors. Wetlands Ecol Manage 26:879-892
Kotowski W, Jabłońska E, Bartoszuk H (2013) Conservation management in fens: do large tracked mowers impact functional plant diversity? Biol Cons 167:292-297

Kozub Ł, Goldstein K, Dembicz I, Wilk M, Wyszomirski T, Kotowski W (2019) To mow or not to mow? Plant functional traits help to understand management impact on rich fen vegetation. Appl Veg Sci 22:27-38

Lai C-T, Ehleringer JR, Tans P, Wofsy SC, Urbanski SP, Hollinger DY (2004) Estimating photosynthetic ${ }^{13} \mathrm{C}$ discrimination in terrestrial $\mathrm{CO}_{2}$ exchange from canopy to regional scales. Global Biogeochem Cycles 18:GB1041. https://doi. org/10.1029/2003GB002148

Laliberté E, Legendre P (2010) A distance-based framework for measuring functional diversity from multiple traits. Ecology 91:299-305

Laliberté E, Legendre P, Shipley B (2014) FD: measuring functional diversity from multiple traits, and other tools for functional ecology. R package version 1.0-12, https:// www.elaliberte.info/publications.

Legendre P, Gallagher ED (2001) Ecologically meaningful transformations for ordination of species data. Oecologia 129:271-280

Legendre P, Legendre L (1998) Numerical ecology. Elsevier Science B. V, Amsterdam

Letten AD, Cornwell WK (2015) Trees, branches and (square) roots: why evolutionary relatedness is not linearly related to functional distance. Methods Ecol Evol 6:439-444

Maechler M, Rousseeuw P, Struyf A, Hubert M, Hornik K (2019) Cluster: cluster analysis basics and extensions. R package version 2.1.0.

Mälson K, Backéus I, Rydin H (2008) Long-term effects of drainage and initial effects of hydrological restoration on rich fen vegetation. Appl Veg Sci 11:99-106

Marquard E, Weigelt A, Roscher C, Gubsch M, Lipowsky A, Schmid B (2009) Positive biodiversity-productivity relationship due to increased plant density. J Ecol 97:696-704

Mayfield MM, Levine JM (2010) Opposing effects of competitive exclusion on the phylogenetic structure of communities. Ecol Lett 13:1085-1093

McBride A, Diack I, Droy N, Hamill B, Jones P, Schutten J, Skinner A, Street M (2011) The fen management handbook. Scottish Natural Heritage, Perth, Scotland

Menichino NM, Fenner N, Pullin AS, Jones PS, Guest J, Jones L (2016) Contrasting response to mowing in two abandoned rich fen plant communities. Ecol Eng 86:210-222

Merriam KE, Markwith SH, Coppoletta M (2018) Livestock exclusion alters plant species composition in fen meadows. Appl Veg Sci 21:3-11

Middleton BA, Holsten B, van Diggelen R (2006) Biodiversity management of fens and fen meadows by grazing, cutting and burning. Appl Veg Sci 9:307-316

Milchunas DG, Sala OE, Lauenroth WK (1988) A generalized model of the effects of grazing by large herbivores on grassland community structure. Am Nat 132:87-106

Moen A, Øien D-I (2002) Ecology and survival of Nigritella nigra, a threatened orchid species in Scandinavia. Nordic Journal of Botany 22:435-461

Moor H, Rydin H, Hylander K, Nilsson MB, Lindborg R, Norberg J (2017) Towards a trait-based ecology of wetland vegetation. J Ecol 105:1623-1635 
Navrátilová J, Hájek M, Navrátil J, Hájková P, Frazier RJ (2017) Convergence and impoverishment of fen communities in a eutrophicated agricultural landscape of the Czech Republic. Appl Veg Sci 20:225-235

Øien D-I, Pedersen B, Kozub Ł, Goldstein K, Wilk M (2018) Long-term effects of nutrient enrichment controlling plant species and functional composition in a boreal rich fen. J Veg Sci 29:907-920

Oksanen J, Blanchet FG, Friendly M, Kindt R, Legendre P, McGlinn D, Minchin PR, O'Hara RB, Simpson GL, Solymos P, Stevens MHH, Szoecs E, Wagner H (2019) Vegan: community ecology package. $\mathrm{R}$ package version 2.5-6, https://cran.r-project.org/package=vegan.

Pagel M (1999) Inferring the historical patterns of biological evolution. Nature 401:877-884

Pakeman RJ (2011) Functional diversity indices reveal the impacts of land use intensification on plant community assembly. J Ecol 99:1143-1151

Pearse WD, Cadotte MW, Cavender-Bares J, Ives AR, Tucker CM, Walker SC, Helmus MR (2015) Pez: phylogenetics for the environmental sciences. Bioinformatics 31:2888-2890

Pillar VD, Blanco CC, Müller SC, Sosinski EE, Joner F, Duarte LDS (2013) Functional redundancy and stability in plant communities. J Veg Sci 24:963-974

Pillar VD, Duarte L.d.S., Sosinski E.E. and Joner F. (2009) Discriminating trait-convergence and trait-divergence assembly patterns in ecological community gradients. J Veg Sci 20:334-348

Pinheiro J, Bates D, DebRoy S, Sarkar D, R Core Team (2019). Nlme: linear and nonlinear mixed effects models. R package version 3.1-141, URL: https://cran.r-project.org/ package $=$ nlme.

Pollock ML, Legg CJ, Holland JP, Theobald CM (2007) Assessment of expert opinion: seasonal sheep preference and plant response to grazing. Rangeland Ecol Manage 60:125-135

Poore MED (1956) The ecology of Woodwalton Fen. J Ecol 44:455-492

R Development Core Team. (2019) R: a language and environment for statistical computing. R Foundation for Statistical Computing, Vienna, Austria

Razafindratsima OH, Brown KA, Carvalho F, Johnson SE, Wright PC, Dunham AE (2018) Edge effects on components of diversity and above-ground biomass in a tropical rainforest. J Appl Ecol 55:977-985

Reich PB, Ellsworth DS, Walters MB, Vose JM, Gresham C, Volin JC, Bowman WD (1999) Generality of leaf trait relationships: A test across six biomes. Ecology 80:1955-1969

Revell LJ (2012) phytools: an R package for phylogenetic comparative biology (and other things). Methods Ecol Evol 3:217-223

Salgado-Luarte C, Escobedo VM, Stotz GC, Rios RS, Arancio G, Gianoli E (2019) Goat grazing reduces diversity and leads to functional, taxonomic, and phylogenetic homogenization in an arid shrubland. Land Degrad Dev 30:178-189

Schrautzer J, Sival F, Breuer M, Runhaar H, Fichtner A (2013) Characterizing and evaluating successional pathways of fen degradation and restoration. Ecol Ind 25:108-120
Si X, Cadotte MW, Zeng D, Baselga A, Zhao Y, Li J, Wu Y, Wang S, Ding P (2017) Functional and phylogenetic structure of island bird communities. J Anim Ecol 86:532-542

Silvertown J, McConway K, Gowing D, Dodd M, Fay MF, Joseph JA, Dolphin K (2006) Absence of phylogenetic signal in the niche structure of meadow plant communities. Proc R Soc B 273:39-44

Sokal RR, Rohlf FJ (2012) Biometry: the principles and practice of statistics in biological research. W. H, Freeman and Company, New York

Staddon PL (2004) Carbon isotopes in functional soil ecology. Trends Ecol Evol 19:148-154

Stammel B, Kiehl K, Pfadenhauer J (2003) Alternative management on fens: response of vegetation to grazing and mowing. Appl Veg Sci 6:245-254

Swenson NG, Enquist BJ, Thompson J, Zimmerman JK (2007) The influence of spatial and size scale on phylogenetic relatedness in tropical forest communities. Ecology 88:1770-1780

Taylor K, Rowland AP, Jones HE (2001) Molinia caerulea (L.) Moench. J Ecol 89:126-144

Tucker CM, Cadotte MW (2013) Unifying measures of biodiversity: understanding when richness and phylogenetic diversity should be congruent. Divers Distrib 19:845-854

Vellend M, Cornwell WK, Magnuson-Ford K, Mooers A (2011) Measuring phylogenetic biodiversity. In: Magurran AE, McGill BJ (eds) Biological diversity: frontiers in measurement and assessment. Oxford University Press, Oxford, UK, pp 194-207

Vinther E, Hald AB (2000) Restoration of an abandoned species-rich fen-meadow in Denmark: changes in species richness and dynamics of plant groups during 12 years. Nordic J Bot 20:573-584

Waller M, Carvalho F, Grant MJ, Bunting MJ, Brown K (2017) Disentangling the pollen signal from fen systems: modern and Holocene studies from southern and eastern England. Rev Palaeobot Palynol 238:15-33

Webb CO, Donoghue MJ (2005) Phylomatic: tree assembly for applied phylogenetics. Mol Ecol Notes 5:181-183

Westoby M (1998) A leaf-height-seed (LHS) plant ecology strategy scheme. Plant Soil 199:213-227

Westoby M, Walker B, Noy-Meir I (1989) Opportunistic management for rangelands not at equilibrium. J Range Manag 42:266-274

Wheeler BD (1980) Plant communities of rich-fen systems in England and Wales: I. introduction. tall sedge and reed communities. J Ecol 68:365-395

Wheeler BD, Giller KE (1982) Species richness of herbaceous fen vegetation in Broadland, Norfolk in relation to the quantity of above-ground plant material. $\mathrm{J}$ Ecol 70:179-200

Wheeler BD, Proctor MCF (2000) Ecological gradients, subdivisions and terminology of north-west European mires. J Ecol 88:187-203

Wheeler BD, Shaw SC (1995) A focus on fens - controls on the composition of fen vegetation in relation to restoration. In: Wheeler BD, Shaw SC, Fojt WJ, Robertson RA (eds) Restoration of temperate wetlands. John Wiley \& Sons Ltd, Chichester, UK, pp 49-72 
Wright IJ, Reich PB, Westoby M, Ackerly DD, Baruch Z, Bongers F, Cavender-Bares J, Chapin T, Cornelissen JHC, Diemer M, Flexas J, Garnier E, Groom PK, Gulias J, Hikosaka K, Lamont BB, Lee T, Lee W, Lusk C, Midgley JJ, Navas ML, Niinemets U, Oleksyn J, Osada N, Poorter H, Poot P, Prior L, Pyankov VI, Roumet C, Thomas SC, Tjoelker MG, Veneklaas EJ, Villar R (2004) The worldwide leaf economics spectrum. Nature 428:821-827

Zanne AE, Tank DC, Cornwell WK, Eastman JM, Smith SA, FitzJohn RG, McGlinn DJ, O’Meara BC, Moles AT, Reich PB, Royer DL, Soltis DE, Stevens PF, Westoby M, Wright IJ, Aarssen L, Bertin RI, Calaminus A, Govaerts R, Hemmings F, Leishman MR, Oleksyn J, Soltis PS, Swenson NG, Warman L, Beaulieu JM (2014) Three keys to the radiation of angiosperms into freezing environments. Nature 506:89-92

Zuur A, Ieno EN, Walker N, Saveliev AA, Smith GM (2009a) Mixed effects models and extensions in ecology with R. Springer-Verlag, New York

Zuur AF, Ieno EN, Walker NJ, Saveliev AA, Smith GM (2009b) Mixed effects modelling for nested data. In: Zuur A, Ieno EN, Walker N, Saveliev AA, Smith GM (eds) Mixed effects models and extensions in ecology with R. Springer, New York, NY, pp 101-142

Publisher's Note Springer Nature remains neutral with regard to jurisdictional claims in published maps and institutional affiliations. 